Riza Yildırım,

\title{
Menâkıb-ı Evliyâ (Buyruk): Taribsel Arka Plan, Metin Analizi, Edisyon- Kritik Metin,
}

İstanbul: Yapı Kredi Yayınları, 2020, 574 s., ISBN 978-975-08-4859-9.

Günümüz Türk tarihçileri arasında Alevilik ve Bektaşilik konusunda çalışmaları ile dikkat çeken araştırmacılardan biri olan Rıza Yıldırım başarılı bir çalışmaya daha imza atarak Alevilik inancının temellerini oluşturan kaynak metinleri, oluşum süreçlerini değerlendiren inceleme ile birlikte yayınladı. Daha önceki iki çalışmasında, Alevilik ve Bektaşiliğin aralarında benzerlik olmakla birlikte oluşum süreci ve sosyolojik tabanı bakımından farklı inanç sistemleri olduğunu tarihî ve itikâdî konulardaki temelleri ile izah eden Rıza Yıldırım bu sefer Alevilik tarihindeki, 16. asır öncesi ile sonrasındaki büyük değişimi Buyruk ve Safevî kaynaklarından yararlanarak açıklamaktadır.

\section{Kızılbaş Sûfîliği}

İlk defa bu çalışmada tesadüf ettiğim, Rıza Yıldırım’ın Safevî tarikatı ile Türkmen dindarlığının kaynaşması sonucu ortaya çıkan bu oluşuma verdiği Kızılbaş Sufîliği ismi ve kavramının, Aleviliğe dair şu ana kadar gördüğüm en kapsayıcı ve açıklayıcı tanım olduğunu söylemeliyim. Ülkemizde özellikle çağrıştırdığı olumsuz anlamların etkisiyle pek tercih edilmeyen Kızılbaş ile Buyruk’ta gördüğümüz şekliyle bir tarikat olan yapısını düşünerek sufiliği ilave ederek üretilen isim kanaatimizce kapsayıcı ve açıklayıcıdır.

Yıldırım’ın Kızılbaş sûfîliğini iki döneme ayırması zihnimizde taşıdığımız bir diğer sorunun cevabı olmuştur. İlk dönem, tarikat özelliğinin daha belirgin olduğu Şeyh Safîden Şeyh Cüneyd'e kadar gelen dönemdir. Şeyh Cüneyd ile başlayıp Şah Tahmasb döneminde tamamlanan süre ise Kızılbaş sûfîliğin teşekkül devri kabul edilmektedir. Yıldırım, bu iki dönem anlayışını adeta iki farklı tarikat olarak değerlendirmektedir. Bu değişim ve farklılaşmada Osmanlı-Safevî çatışmasının da rolü olduğu düşünülebilir.

Rıza Yıldırım’ın üzerinde ısrarla durduğu konulardan biri de Kızılbaşsufiliğinin asker tarikatı olduğu ve Safevi devletinin yönetici kadrosunun tarikatı olmasıdır. İranlılar devlet yönetimine girdikçe tarikat zayıflayacak, zamanla İran 
topraklarından çekilip Anadolu’ya yerleşecek ve varlığını büyüyüp geliştiği topraklarda değil, mücadele ettikleri devletin topraklarında sürdüreceklerdir.

Rıza Yıldırım’ın çalışmasında önemli bulduğum ve alana katkıda bulunduğu taraflardan biri kendisinden önce yapılan Köprülü, Togan, Gölpınarlı, Ocak gibi alanın önemli isimlerinin verdiği kimi bilgileri tashih etmesidir. Düzeltilen bilgiler arasında kitap isimleri, müellifler ve olaylar ile birtakım ezberlenmiş ve klişeleşmiş kanaatler bulunmaktadır. Kanaatimizce kitabın özgün yanlarından biri de bu tür bilgilerdir. Yıldırım’n, Aleviliğin kökenlerinin Yesevilik, Bektaşilik ve Kalenderilik merkezli olduğu şeklindeki yaygın kanaatin yanlış olduğunu, Alevilerin kendi gerçeklikleriyle örtüşmediğini iddia etmesi önemli bulduğum bir diğer görüştür. Yazar bu iddiasına gerekçe olarak ise, Aleviliğin temeli olduğu iddia edilen tarikatların ve yolların temel metinlerinde, Aleviliğin olmazsa olmaz dört temel uygulaması olan dede-talip ilişkisi, musahiplik, görgü düşkünlük ve cem ibadetine dair bilginin olmamasını gösterir. Rıza Yıldırım’ın bu gerekçelerini ikna edici bulduğumu söylemeliyim.

Rıza Yıldırım bu iddiasıyla, günümüzde Alevilik ile birlikte dile getirilen Horasan erenleri, Yesevilik ve Anadolu irfânı ile başlayan açıklamaların da aslında temeli olmadığını ifade etmiş olmakta. Kızılbaş sûfiliğinin kurucu metni Buyruk'ların ilk müellifi ve Rıza Yıldırım’ın Kızılbaş sufiliğini iki döneme ayırarak "ilk dönem sufiliği” olarak adlandırdığı dönemin kurucusu Şeyh Safî̀nin Halvetiyyenin iki kolundan birinin, Erdebiliyye’nin kurucusu olduğunu, diğeri Bayramiye, ve Kızılbaş Sufîliğinin de bu koldan neş'et ettiğini düşündügümüzde aslında Erdebilîğin aynı dönem Anadolu’da yaygın diğer tarikatlardan farklı olmadığını söyleyebiliriz. Rıza Yıldırım’ın özellikle Buyruk’u, yazıldığı dönemin diğer metinleri ile mukayese ederken ortaya koyduğu benzerlikler de bu görüşü desteklemekte. Bu durumda Kızılbaşs sûfiliği Erdebiliyyenin Şeyh Cüneyd ile değişmeye başlayan bir tarikat olduğunu ve Bektaşilîk dahil diğer tarikatlardan ayrıştığını söylemek mümkündür.

Halvetiye silsilesi Anadolu'da ikiye ayrılır. İbrâhim Zâhid-i Geylânî nin büyük halifelerinden Sadeddîn-i Fergânî ile Halvetiyye silsilesi ve Safîyüddîn Erdebîlî ile de Safeviyye, bir diğer deyişle Erdebiliyye ve Bayramiyye silsileleri teselsül eder. Alevîliğin temelini oluşturan Erdebîliyye ile Bayramiyye arasındaki yakınlık ve benzerlik Bektaşîlikten çok daha fazla olması bilinen birçok ezber düşünceyi sarsmakta. Anadolu'da gelişen İslam inanç ve ibadet hayatını anlamak için bu iki kolu çok iyi incelemek gerekmektedir. 
Rıza Yıldırım’ın çalışmasında ileri sürdüğü iddialardan bir diğeri Buyruk gibi metinlerin layıkı veçhile değerlendirildiği takdirde Alevilik araştırmalarında bir eksen değişikliğine gidileceğine olan inancıdır. Bu tür metinlerin Alevilik hakkındaki çalışmalara büyük katkı sağlayacağına inanmakla birlikte günümüz Alevi toplumlarında, özellikle Batı Avrupa'da örgütlenenler arasında bir ilgi uyandıracağını ve değiştireceğine olan inancımızın oldukça zayıf olduğunu söylemeliyim.

Rıza Yıldırım’ın bu çalışması, tamamen şifahî kültüre dayalı olduğu söylenen Aleviliğin yazılı kaynaklarının sanılandan daha fazla olduğuna dikkat çekmektedir.

Alevilikle ilgili tartışmalardan biri Aleviliğin tarikat, cemaat, din veya mezhep olup olmadığıdır. Rıza Yıldırım bu çalışması ve teklif ettiği isimlendirme ile bu soruya cevap vermektedir. Rıza Yıldırım’ın da ısrarla üzerinde durduğu ve en azından benim ilk defa duyduğum "Kızılbaş Sufiliğii" isimlendirmesi ile bir tarikat olduğunu öğreniyoruz. Metni verilen Buyruk’a göz attığımızda da Aleviliğin bir tarikat olduğunu açık bir şekilde görüyoruz.

Kitapta Alevi tarihinde yeterince vuzuha kavuşmamış konu, kanaatimce Safeviler öncesi dönemdir. Ahmet Yaşar Ocak'ın Safeviler öncesi Alevi tarihine dair tezlerini daha makul bulduğumu ifade etmeliyim.

Buyruk metninin yayınlanmasına rağmen Alevi tarihi içinde yazılı kaynaklar meselesinin hâlâ sorunlu olduğunu düşünüyorum. Elimizde en azından şimdilik, Buyruk dışında başka metin yok gibi durmakta. Rıza Yıldırım'ın Aleviliğin temel metinleri arasında zikrettiği, aralarında edebi metinlerin de yer aldığı eserlerin önemli bir kısmı Selçuklu Türkiye'si ile Osmanlı Balkanlarında yaşayan kendilerini Alevî olarak görmeyen Türkler arasında da okunan metinler olmasından dolayı, münhasıran Aleviliğe hasretmek yerine daha çok Anadolu'da gelişen halk inancının temellerini oluşturan metinler olarak görmek ve değerlendirmek daha doğru olacaktır. Buyruk'ta dile getirilen ehl-i beyt sevgisi, Bektaşiliği bir kenara bırakacak olursak, Kâdirî ve Halvetîlerde de en az Erdebilîler kadar olduğunu söyleyebiliriz. Ayrıca fütüvvetname metinleri ile aralarında görülen benzerliğe de dikkat edilmelidir.

\section{Buyruk bir Kitap Adı mıdır, Yoksa bir Tür Adı mıdır?}

Buyruk üzerinde yapılan tartışmalardan biri de Buyruk’un kitap adı mı yoksa bir tür mü olduğu meselesidir. Yıldırım, bir metnin buyruk olup olmayacağına karar verilmesi için dikkat edilmesi gereken özelliklerin neler olduğunun belli 
olmadığını söyler. Hiç şüphesiz burada tür derken edebi bir türden bahsedilmemektedir. Böyle bir soru soru, içinde, buyrukların müstakil kitap olmadığı iddiasını barındırmaktadır. Buyruk metnini okuduktan sonra zihnimde, Rıza Yıldırım'ın yüzlerce nüsha görerek ulaştığı ve benim çok değerli ve anlamlı bulduğum yargıdan kısmen farklı bir kanaat oluştuğunu ifade etmeliyim. Kanaatimce Buyruk, Yıldırım'ın da işaret ettiği gibi bir seferde bir müellif tarafından oturulup yazılan bir eser değildir. Aleviliğin tarikatlaşma sürecinde ki bu neredeyse bir asra yakın bir süredir, zaman içinde farklı kişiler tarafından telif edilmiş olmalıdır. Zaman içinde ilk yazılan metinlere de ilaveler yapıldığı, özellikle Sûfî Kızılbaşlığın kurucusu Şah İsmail'in yazdığı şiirlerin dedesinin yazdığı metin içinde yer almasından anlaşılmaktadır. Nüshalar arasındaki farklılık ise istinsah ve ihtiyaçtan kaynaklanmakta olup ciddi bir fark oluşturmamaktadır. Özetleyerek alınan bir metin, istinsah edilirken yeterince açık bulunmadığı için açıklamalar ile genişlemekte ve bu durumun yaygın olması da özü ve ruhu olan metinlerin lafızlarında farklılıklar meydana getirmektedir. Dolayısıyla Buyruk bir eser olup Rıza Yıldırım'n tespit ettiği yüzlerce nüsha temel metnin özet, açıklama ve dipnot dediğimiz bazen sayfa kenarlarına bazen de metin içine düşülen özel notlarından oluşmaktadır. Kanaatimizce, Şeyh Sâfî Buyruk'u tek eserdir, ama, muhtasar, şerh ve haşiyeleri çoktur. Bunun nedenlerini ise Rıza Yıldırım eserinde çok açık bir şekilde izah etmektedir. Kimi araştırmacıların aksine her Buyruk metninin özgün bir eser olarak kabul etmemiz pek mümkün görünmemektedir. Böyle düşünmemizin nedeni metinlerin müstakilen ve yeniden yazılmamış olmasıdır. Dolayısıyla ikinci nesil akademisyenlerin Buyruk'un bir edebi tür olarak ele alınması gerektiğine dair düşüncelerine katılmamız pek mümkün görünmemektedir. Rıza Yıldırım'ın Buyruk'u kök metin olarak kabul etmesi daha ma'kul olup Kızılbaş sûfiliği bu metin üzerine inşâ edilmiştir.

Kitapta Yıldırım'ın katılmadığım bir diğer görüşü Buyruk'un dinamik bir edebi tür olarak tanımlanmasıdır. Buyruk'un edebi bir tür olmadığını ve tek bir eser olduğunu, elde mevcut nüshaların farklı amaçlarla Buyruk'tan üretildiğini düşünüyorum. Her bir Buyruk metninin özgün olduğu görüşüne katılmamı, en azından şu anki bilgilerime göre pek mümkün görünmemektedir. Zaten kendisi de bu görüşünde çok emin olmadığı için olsa gerek bir başka yerde (s. 52) çalı̧̧masında bir kök metin olduğu, diğer nüshaların bu metinden beslendiğini ifade etmektedir.

Buyruk metninin manzum-mensur olarak ikiye bölümden oluştuğu ifadesinin de tashih edilmesi gerektiğini düşünmekteyim. Metinler görüldüğü kadarı ile 
mensurdur. Kimi metinlere sonradan ilave edildiği anlaşılan başta Hatayi olmak üzere kimi Alevilerin ulu ozanlarının konu ile ilgili deyişleri ve nefesleri ilave edilmiştir. Metin ağırlıklı olarak mensur olmakla birlikte kimi bölümleri mensurmanzum karışıktır.

Sekiz farklı metnin bir araya getirildiği Buyruk'a, bir mecmua, bir külliyat da denilebilir. Yıldırım da bunu "kü̧̧ük risalelerin, yerleşmiş uygulamaların derlenip düzenlenerek iki kapak arasında toplanmasindan ibaret" (s. 166) şeklinde izah etmektedir. Tek seferde yazılmayıp ihtiyaç duyuldukça yazılması yönüyle de müstakil bir eser kabul edilmesi doğru olmasa gerek. Mecmuada yer alan her eser tarikatın bir yönüne işaret etmekte, dervişlerin eğitimini tamamlamaktadır.

Mecmuada Menâkıb-ı Evliyầnın yani Buyruk'un ilk bölümü bir nevi Kızılbaş sûfiliği itikat ve ilmihal kitabı mahiyetindedir. Metinlerdeki manzum kısımların artması ve metnin bir parçası olmasından da anlaşıldığı gibi özellikle Nesebnâme ve sonrasındaki eserler sonradan kaleme alınmış eserlerden oluşmaktadır. En sonda yer alan hatime ise risaleleri derleyen tarafından yazılmış olmalıdır.

Son olarak Rıza Yıldırım'ın her türlü takdiri hak eden bu eserini iki konuda eleştirilebileceğini ifade etmek isterim. İlki neredeyse tamamen Safevî kaynaklarına dayanılarak hazırlandığı için Safevî bir bakış açısının hâkim olduğu ve Anadolu'nun tesiri ve etkisinin biraz geride kalmasıdır. Diğeri ise bu tür çalışmalarda olması normal olan ve daha sonraki baskılarda düzeltileceğini düşündüğüm, metnin imlasında ve okunmasında kimi küçük yanlışların ve tashihlerin bulunmasıdır.

\section{İsmail Güleç}

İstanbul Medeniyet Üniversitesi 